\title{
KERAGAMAN GENETIK ANAKAN Shorea leprosula \\ BERDASARKAN PENANDA MIKROSATELIT
}

Genetic Diversity of Shorea leprosula Offspring

Based on Microsatellite Markers

\author{
Purnamila Sulistyawati, AYPBC Widyatmoko, ILG Nurtjahjaningsih \\ Balai Besar Penelitian Bioteknologi dan Pemuliaan Tanaman Hutan \\ Jl. Palagan Tentara Pelajar Km 15, Purwobinangun, Pakem, Sleman, Yogyakarta 55582 \\ E-mail : purnamila_mila@yahoo.com
}

\begin{abstract}
Genetic diversity value of offspring might indicate a reproductive success in a forest. Aim in this study was to access genetic diversity values of offspring of Shorea leprosula from different forest types. Leaf samples were collected from six population i.e. a plantation from Carita, and five natural forests from Gunung Bunga A and B, SBK, ITCI and Gunung Lumut. Using four microsatellite markers, the results showed that SBK population maintained high value of genetic diversity. Values of expected heterozygosity $\left(H_{E}\right)$ ranged between 0.717 (Carita) and 0.836 (SBK). Values of coefficient inbreeding $(F)$ were insignificant deviated from Hardy-Weinberg Equilibrium, but the value was significant in SBK population. PCA analysis demonstrated a cluster among Gunung Bunga A, SBK, ITCI, and Gunung Lumut. Amova showed that different province significantly contributed 1\% to the value of genetic diversity of $S$. leprosula.
\end{abstract}

Key words: Shorea leprosula, offspring, genetic diversity, microsatellite

\begin{abstract}
ABSTRAK
Nilai keragaman genetik keturunan suatu jenis tanaman merupakan salah satu faktor keberhasilan reproduksi dalam hutan. Tujuan dalam penelitian ini adalah untuk mengetahui keragaman genetik keturunan/anakan Shorea leprosula dari populasi hutan alam dan tanaman. Sampel daun dikumpulkan dari enam populasi yaitu 1 populasi dari hutan tanaman (Carita), dan lima hutan alam di Kalimantan (Gunung Bunga A dan B, SBK, ITCI dan Gunung Lumut). Menggunakan empat penanda mikrosatelit, hasil penelitian menunjukkan bahwa populasi SBK mempunyai nilai keanekaragaman genetik tertinggi dibandingkan populasi lainnya. Nilai heterozigositas yang diharapkan (He) berkisar antara 0,717 (Carita) dan 0,836 (SBK). Nilai koefisien perkawinan kerabat (F) tidak signifikan menyimpang dari Hardy-Weinberg Equilibrium, tetapi signifikan dalam populasi SBK. Analisis PCA menunjukkan klaster antara Gunung Bunga A, SBK, ITCI, dan Gunung Lumut. Hasil Amova menunjukkan bahwa provinsi yang berbeda memberikan kontribusi $1 \%$ terhadap nilai keragaman genetik anakan S. leprosula.
\end{abstract}

Kata kunci: Shorea leprosula, anakan, keragaman genetik, microsatellite 


\section{PENDAHULUAN}

Keragaman genetik merupakan salah satu faktor penting dalam mempertahankan keberadaan suatu jenis. Suatu populasi dengan keragaman genetik tinggi, mempunyai kemampuan untuk mempertahankan diri dari serangan penyakit dan perubahan iklim ekstrim, sehingga mampu hidup dalam kondisi lestari pada beberapa generasi. Tingkat keragaman genetik merupakan salah satu faktor penentu dalam keberhasilan strategi pemuliaan maupun konservasi. Nilai keragaman genetik suatu populasi tergantung juga pada keberhasilan sistem reproduksi pada populasi tersebut. Keragaman genetik dapat dipertahankan apabila tidak terjadi kawin sendiri (selfing) atau kawin kerabat (inbreeding) (Tani dkk., 2009). Laju sistem reproduksi bergantung juga pada sinkronisasi fenologi pembungaan dan faktor lingkungan seperti kerapatan dan tinggi pohon (Tani dkk., 2009). Sinkronisasi pembungaan sering tidak terjadi pada individu-individu pohon baik di hutan alam maupun hutan tanaman apabila tahun tanamnya berbeda atau berasal dari provenan atau populasi yang berbeda.

Shorea leprosula adalah salah satu anggota Dipterocarpaceae yang bernilai ekonomi dan ekologi tinggi, merupakan tanaman dominan hutan tropis di Asia Tenggara termasuk Indonesia. Di Indonesia, sebaran alam jenis ini cukup luas, meliputi Sumatera dan Kalimantan. S. leprosula mempunyai gamet jantan dan betina pada bunga yang sama (hermaprodite) dengan sistem perkawinan dominan outcrossing yang dibantu oleh serangga. Jenis ini memiliki karakter pembungaan yang tidak teratur, bahkan hingga empat tahun sekali berbunga. Usaha konservasi in-situ, eks- situ (Glaubitz dan Moran, 2000; Siregar, 2001; Soekotjo, 2001; Suseno, 2001) maupun strategi pemuliaan pada jenis ini sudah banyak dilakukan (Lemmens dan Soerianagara, 1994; Rudjiman, 1997; Sastrapradja dkk., 1997; Lee, 2000; Rudjiman dan Adriyanti, 2002; Adriyanti dkk., 2005; Lestyaningsih dkk., 2005; Nai'em dkk., 2005; Fukue dkk., 2007; Sayektiningsih, 2010).

Mikrosatelit atau simple sequence repeat (SSR) merupakan salah satu penanda DNA yang mempunyai sekuen sederhana, terdiri dari satu hingga enam basa yang diulang, dan banyak dijumpai pada genom tanaman (Tauntz, 1989; Chase dkk., 1996; Butcher dkk., 1999; Tani dkk., 2009). Sekuen mikrosatelit tidak diterjemahkan sebagai asam amino pada sintesa protein (non-coding), 
bersifat ko-dominan dan diturunkan. Tingkat polimorfisme yang tinggi menyebabkan penanda mikrosatelit mampu membedakan populasi, jenis dan individu yang berkerabat secara genetik (Butcher dkk., 1999).

Tujuan penelitian ini adalah untuk mengetahui tingkat keragaman genetik anakan dari enam populasi $S$. leprosula menggunakan penanda mikrosatelit. Hasil penelitian ini diharapkan dapat mengetahui keragaman genetik anakan dari masing-masing populasi untuk memilih dan menentukan jumlah anakan yang akan digunakan untuk materi genetik uji klon S. leprosula.

\section{BAHAN DAN METODE}

\section{A. Deskripsi lokasi pengambilan sampel}

Sampel daun anakan $S$. leprosula umur 1 tahun dikumpulkan dari persemaian Balai Besar Penelitian Dipterokarpa, Samarinda (Kalimantan Timur). Anakan tersebut berasal dari 6 populasi yaitu Carita (Jawa Barat), Gunung Bunga A (GBA, Kalimantan Barat), Gunung Bunga B (GBB, Kalimantan Barat), Sari Bumi Kusuma (SBK, Kalimantan Tengah), PT. ITCI Kenangan (ITCI, Kalimantan Timur) dan Gunung Lumut (GL, Kalimantan Timur) (Gambar 1). Populasi Carita merupakan hutan tanaman yang terletak di kawasan hutan dengan tujuan khusus (KHDTK), sedangkan lima populasi dari Kalimantan merupakan hutan alam (Rayan dan Cahyono, 2012). Populasi Gunung Bunga merupakan hutan alam di areal izin usaha pemanfaatan hasil hutan kayu (IUPHHK) PT. Suka Jaya Makmur (PT. SJM), Tanjung Bunga (Kalbar). Populasi SBK merupakan hutan alam di areal IUPHHK di PT. Sari Bumi Kusuma (Kalteng). Populasi ITCI merupakan hutan alam di areal IUPHHK PT. ITCIKU, Kenangan (Kaltim). Populasi Gunung Lumut merupakan kawasan hutan di Kabupaten Pasir (Kaltim).

Jumlah pohon induk dari masingmasing populasi yang dikoleksi disajikan pada Tabel 1, sedangkan jumlah sampel per populasi yang digunakan untuk analisis DNA sebanyak 48 individu yang berasal dari 4-6 pohon induk yang dipilih secara acak. 
Tabel 1. Jumlah pohon induk dari masing-masing populasi $S$. leprosula yang dikoleksi (Rayan dan Cahyono, 2012)

\begin{tabular}{lcc}
\hline Populasi & Tipe hutan & $\begin{array}{c}\text { Jumlah pohon } \\
\text { induk }\end{array}$ \\
\hline Carita & Tanaman & 18 \\
GB & Alam & 9 \\
SBK & Alam & 12 \\
ITCI & Alam & 20 \\
GL & Alam & 24 \\
\hline
\end{tabular}

\section{B. Ekstraksi DNA dan analisis mikrosatelit}

Total DNA sampel daun $S$. leprosula diekstraksi menggunakan metode modifikasi CTAB (Shiraishi dan Watanabe, 1995). Total volume PCR adalah $10 \mu$ l yang tersusun dari $10 \times$ EDTA buffer $25 \mathrm{mM} \mathrm{MgCl}, 25 \mathrm{mM}$ dNTP, 10

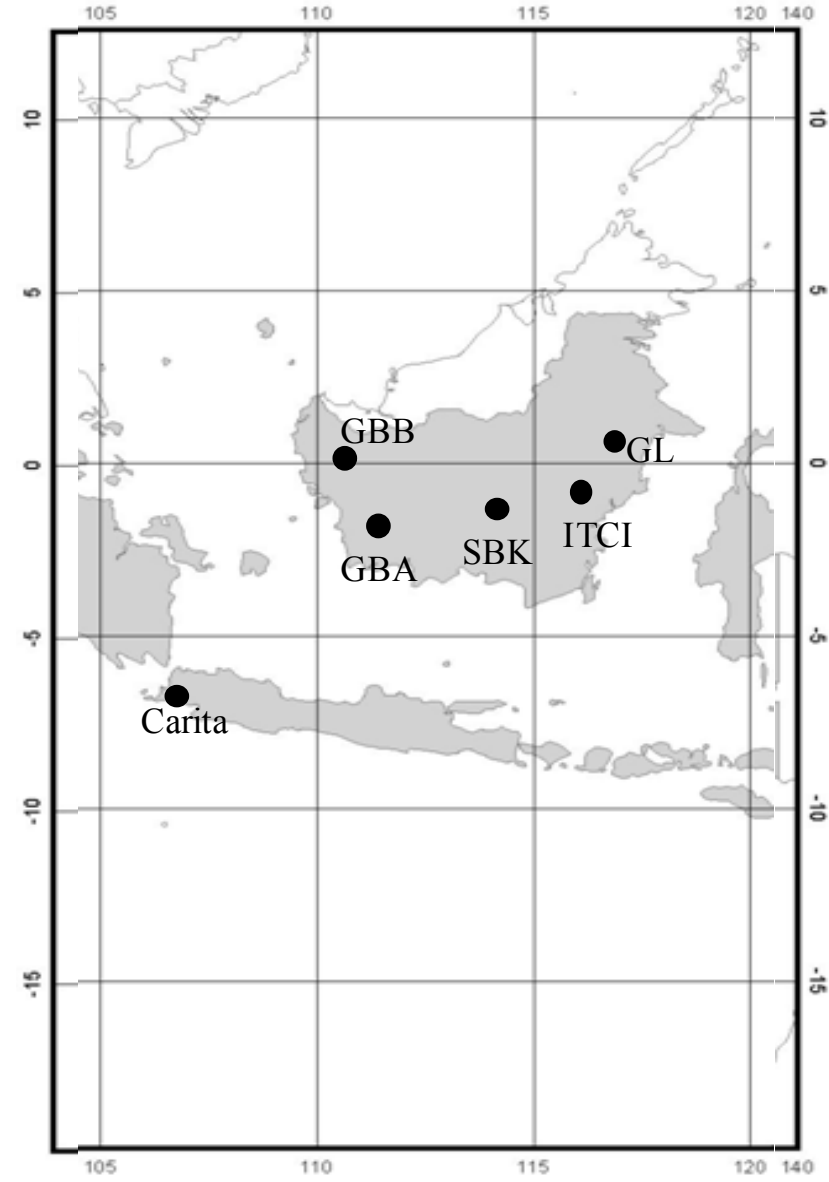

Gambar 1. Lokasi dari enam populasi S. leprosula $\mu \mathrm{M}$ masing-masing pasangan primer mikrosatelit, 5 U Amplitaq Gold Polymerase (Applied Biosystem) dan 10 ng larutan DNA. Amplifikasi dilakukan menggunakan thermocycler GeneAmp 9700 (Applied Biosystems). Penelitian ini menggunakan empat penanda mikrosatelit yang dikembangkan dari Shorea curtisii (Ujino dkk., 1998) yang ditunjukkan pada Tabel 2.

Tabel 2. Sekuen primer dan motif ulangan mikrosatelit pada S. curtisii (Ujino dkk., 1998)

\begin{tabular}{|c|c|c|c|c|c|}
\hline Lokus & Sekuen basa ( $\left(5^{\prime}-3^{\prime}\right)$ & Motif ulangan & $\begin{array}{c}\text { T. ann } \\
\left({ }^{\circ} \mathrm{C}\right)\end{array}$ & $N_{\mathrm{a}}$ & $\boldsymbol{H}_{\mathrm{E}}$ \\
\hline Shc-1 & $\begin{array}{l}\text { GCTAT TGGCA AGGAT GTTCA } \\
\text { CTTAT GAGAT CAATT TGACA G }\end{array}$ & $\begin{array}{l}(\mathrm{CT})_{8}(\mathrm{CA})_{10} \mathrm{CT}(\mathrm{CA})_{4} \\
\text { CTCA }\end{array}$ & 56 & 20 & 0,922 \\
\hline Shc-2 & $\begin{array}{l}\text { CACGC TTTCC CAATC TG } \\
\text { TCAAGA GCAGA ATCCA G }\end{array}$ & $(\mathrm{CT})_{2} \mathrm{CA}(\mathrm{CT})_{5}$ & 54 & 2 & 0,180 \\
\hline Shc-7 & $\begin{array}{l}\text { ATGTC CATGT TTGAG TG } \\
\text { CATGG ACATA AGTGG ATG }\end{array}$ & $\begin{array}{l}(\mathrm{CT})_{8} \mathrm{CA}(\mathrm{CT})_{5} \mathrm{CACCC} \\
(\mathrm{CTCA})_{3} \mathrm{CT}(\mathrm{CA})_{10}\end{array}$ & 54 & 11 & 0,810 \\
\hline Shc-9 & $\begin{array}{l}\text { TTTCT GTATC CGTGT GTTG } \\
\text { GCGATT AAGCG GACCT CAG }\end{array}$ & $(\mathrm{CT})_{12}$ & 54 & 9 & 0,818 \\
\hline
\end{tabular}

Keterangan: T. ann: suhu penempelan primer, $N_{\mathrm{a}}$ : jumlah allele yang terdeteksi, $H_{\mathrm{E}}$ : Heterozigositas harapan per lokus 
Proses PCR dilakukan menggunakan thermocycler GeneAmp9700 (Applied Biosystem). Suhu pemanasan awal $94^{\circ} \mathrm{C}$ selama 10 menit, diikuti dengan 10 siklus reaksi yang masing-masing terdiri dari denaturasi DNA (suhu $94^{\circ} \mathrm{C}$ selama 30 detik), penempelan primer (annealing) mengikuti protokol touchdown pada suhu $60^{\circ}-50{ }^{\circ} \mathrm{C}$ selama 30 detik dan pemanjangan DNA pada suhu $72^{\circ} \mathrm{C}$ selama 60 detik. Kemudian diikuti 20 siklus yang terdiri dari denaturasi dan pemanjangan DNA seperti yang disebutkan diatas dan reaksi penempelan primer pada suhu $50^{\circ} \mathrm{C}$ selama 30 detik. Siklus PCR diakhiri pada suhu $72^{\circ} \mathrm{C}$ selama 1 menit untuk melengkapi proses pemanjangan. Elektroforesis hasil PCR menggunakan mesin gene analyzer ABI 3100 Avant (Applied Biosystem). Fragment DNA dianalisis menggunakan software Genemapper.

\section{Analisis Data}

Parameter keragaman genetik di dalam populasi yaitu jumlah allele yang terdeteksi $\left(\mathrm{N}_{\mathrm{a}}\right)$, nilai heterozygositas yang teramati $\left(H_{\mathrm{O}}\right)$, nilai heterozygositas harapan $\left(H_{\mathrm{E}}\right)$ dan koefisien inbreeding $(F)$, dianalisis menggunakan program GenAlex 6.4 (Peakall dan Smouse, 2006).

Analisis prinsip kordinat (PCA) menggambarkan kedekatan secara genetik yang dihubungkan dengan posisi geografis. Selain itu, untuk mengetahui pengaruh propinsi (wilayah), antar populasi dalam propinsi dan di dalam populasi yang berkontribusi terhadap perbedaan keragaman genetik menggunakan Analisis Molekuler Varians (AMOVA). Sumber keragaman genetik pada analisis AMOVA menguji pengaruh empat propinsi yaitu Jawa (Carita), Kalbar (GBA dan GBB), Kalteng (SBK) dan Kaltim (ITCI dan GL), terhadap nilai

Tabel 3. Parameter keragaman genetik ( \pm standar deviasi) di dalam enam populasi anakan S. leprosula

\begin{tabular}{lccccc}
\hline \multicolumn{1}{c}{ Populasi } & $\mathbf{N}$ & $\mathbf{N}_{\mathrm{a}}$ & $\boldsymbol{H}_{\mathbf{0}}$ & $\boldsymbol{H}_{\mathbf{E}}$ & \multicolumn{1}{c}{$\boldsymbol{F}$} \\
\hline Carita & 48 & $8 \pm 2$ & $0,724 \pm 0,06$ & $0,717 \pm 0,09$ & $-0,039 \pm 0,09 \mathrm{~ns}$ \\
GBA & 48 & $11 \pm 2$ & $0,760 \pm 0,06$ & $0,783 \pm 0,04$ & $0,030 \pm 0,04 \mathrm{~ns}$ \\
GBB & 48 & $10 \pm 1$ & $0,724 \pm 0,07$ & $0,724 \pm 0,04$ & $0,004 \pm 0,05 \mathrm{~ns}$ \\
SBK & 48 & $13 \pm 3$ & $0,733 \pm 0,05$ & $0,836 \pm 0,03$ & $0,123 \pm 0,04^{*}$ \\
ITCI & 48 & $12 \pm 3$ & $0,739 \pm 0,08$ & $0,755 \pm 0,06$ & $0,026 \pm 0,04 \mathrm{~ns}$ \\
GL & 48 & $10 \pm 1$ & $0,719 \pm 0,10$ & $0,780 \pm 0,05$ & $0,078 \pm 0,12 \mathrm{~ns}$ \\
\hline
\end{tabular}

Ket: N: Jumlah sampel, $\mathrm{N}_{\mathrm{a}}$ : Jumlah allele yang terdeteksi, $H_{\mathrm{O}}$ : Heterozygositas teramati, $H_{\mathrm{E}}$ : Heterozygositas harapan, $F$ : Koefisien inbreeding ns: nilai $\mathrm{F}$ tidak nyata, * nilai $\mathrm{F}$ nyata pada $P$ value $<0,05$ 
keragaman genetik. PCA dan AMOVA dianalisis menggunakan program GenAlex 6.4.

\section{HASIL DAN PEMBAHASAN}

\section{A. Hasil}

Parameter keragaman genetik pada masing-masing populasi S. leprosula ditunjukkan pada Tabel 3. Jumlah allele yang terdeteksi pada masing-masing populasi berkisar antara 8 (Carita) sampai dengan 13 (SBK). Nilai keragaman genetik yang teramati cukup tinggi dengan ratarata 0,733 dan berkisar antara 0,719 (GL) sampai dengan 0,760 (GBA). Keragaman genetik yang diamati sedikit berbeda atau sama dibandingkan nilai keragaman genetik harapan dari masing-masing populasi, kecuali pada populasi Carita. Hal ini menyebabkan nilai koefisien perkawinan kerabat (inbreeding) tidak nyata menyimpang dari hukum kesimbangan Hardy-Weinberg, kecuali pada populasi SBK.

Analisis PCA menunjukkan hubungan antara kedekatan letak geografis populasi dan jarak genetik. Analisis PCA pada ordinat 1 menunjukkan nilai kepercayaan yang tinggi (hampir 40\%) dan mengelompokkan populasi anakan GBA, SBK, ITCI dan GL, sedangkan populasi Carita dan GBB terpisah dari kelompok tersebut (Gambar 2).

AMOVA menunjukan bahwa semua sumber variasi memberikan nilai yang nyata berpengaruh terhadap nilai keragaman genetik populasi anakan $S$. leprosula, bahkan sumber variasi antar propinsi memberikan hanya $1 \%$ terhadap nilai keragaman genetik namun nilainya signifikan (Tabel 4).

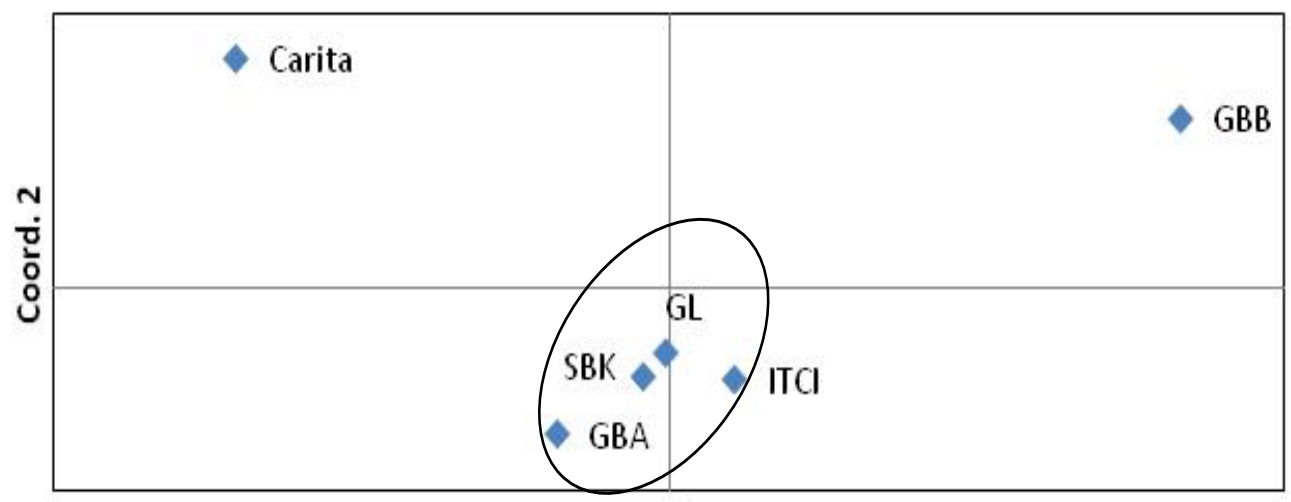

Coord. 1

Gambar 2. Analisis PCA enam populasi anakan S. leprosula menggunakan empat penanda mikrosatelit 
Tabel 4. Analisis Molekular Varian (AMOVA) enam populasi anakan S. leprosula

\begin{tabular}{lccrrrr}
\hline Sumber variasi & $\begin{array}{c}\text { Derajat } \\
\text { Bebas }\end{array}$ & $\begin{array}{c}\text { Jumlah } \\
\text { Kuadrat }\end{array}$ & $\begin{array}{c}\text { Rerata } \\
\text { Kuadrat }\end{array}$ & \% varian & $\boldsymbol{P}$-value \\
\hline Antar propinsi & 3 & 86,913 & 28,971 & 1 & $*$ \\
Antar populasi di dalam propinsi & 2 & 54,677 & 27,339 & 13 & $* *$ \\
Di dalam populasi & 282 & 927,688 & 3,290 & 86 & $*$ \\
Total & 287 & 1069,278 & & 100 & \\
\hline
\end{tabular}

Ket. ${ }^{*} p$-value $<0.05 ; * * p$-value $<0.01$

Berdasarkan pada 4 (empat) penanda mikrosatelit yang digunakan, diketahui bahwa jarak genetik antar populasi tertinggi adalah antara populasi Gunung Bunga B (GBB) dan populasi Carita sebesar 0,591, dan yang terendah adalah antara populasi Gunung Lumut dan populasi ITCI sebesar 0,178 (Tabel 5). Rata-rata jarak genetik dari
6 populasi adalah 0,327 .

Jarak genetik antara populasi anakan $S$. leprosula disusun dalam dendogram dengan metode UPGMA seperti yang digambarkan pada Gambar 3.

Tabel 5. Jarak genetik antar populasi anakan S. leprosula menggunakan penanda mikrosatelit (SSR)

\begin{tabular}{lrrrrrr}
\hline \multicolumn{1}{c}{ Populasi } & Carita & $\begin{array}{l}\text { Gunung } \\
\text { Bunga A }\end{array}$ & $\begin{array}{l}\text { Gunung } \\
\text { Bunga B }\end{array}$ & ITCI & $\begin{array}{c}\text { Gunung } \\
\text { Lumut }\end{array}$ & SBK \\
\hline Carita & - & & & & & \\
Gunung Bunga A & 0,334 & - & & & & \\
Gunung Bunga B & 0,591 & 0,460 & - & & & \\
ITCI & 0,373 & 0,263 & 0,343 & - & & \\
Gunung Lumut & 0,324 & 0,291 & 0,368 & 0,178 & - \\
SBK & 0,335 & 0,179 & 0,373 & 0,290 & 0,208 & - \\
\hline
\end{tabular}

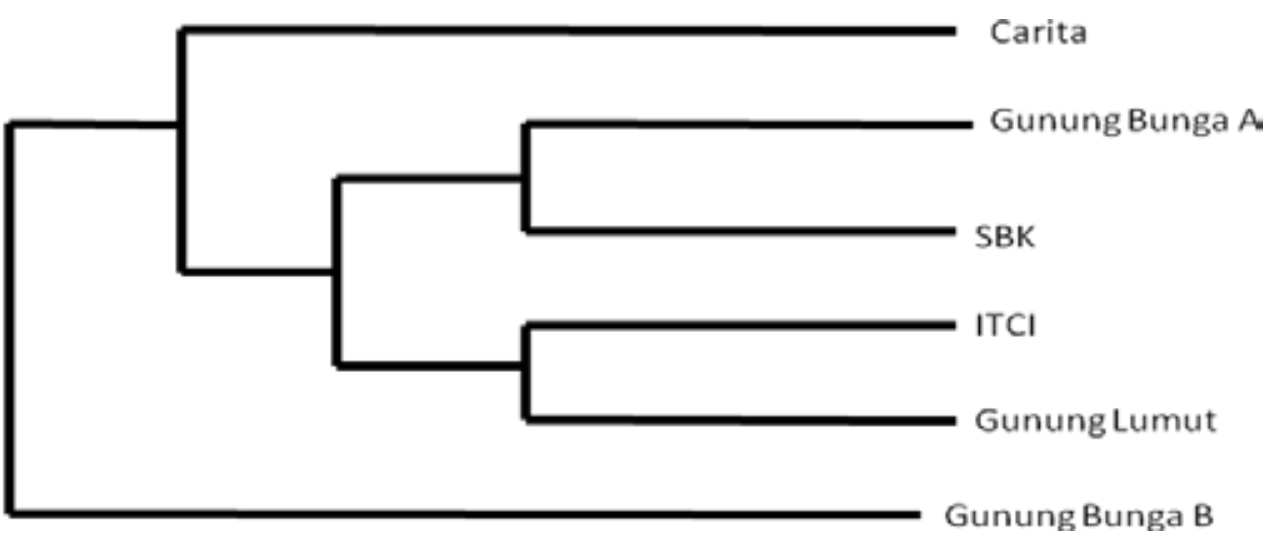

Gambar 3. Dendrogram jarak genetik antar populasi anakan S. leprosula berdasarkan perhitungan Nei's (1978) dengan metode UPGMA 


\section{B. Pembahasan}

Nilai keragaman genetik populasi anakan S. leprosula pada penelitian ini termasuk dalam kategori tinggi (rata-rata $\left.H_{\mathrm{o}}=0,733\right)$, lebih tinggi apabila dibandingkan dengan jenis Dipterocarpaceae lainnya (Murawski dan Bawa, 1994; Lee dkk., 2000; Cao, 2006; Cao dkk., 2009). Nilai keragaman genetik anakan ini juga lebih tinggi bila dibandingkan dengan penelitian keragaman genetik S. leprosula yang berasal dari Jambi dan Kaltim yang juga menggunakan metode mikrosatelit (Isoda dkk., 2001; Rimbawanto dan Isoda, 2001); metode RAPD (Rimbawanto dan Suharyanto, 2005; Prihatini dkk., 2001); metode isoenzim (Lee, 2000) dan metode AFLP (Cao dkk., 2009).

Nilai keragaman genetik anakan yang berbeda-beda menunjukkan keragaman pohon induk dan sistem perkawinan yang terjadi pada masing-masing populasi. Nilai heterosigositas harapan $(\mathrm{He})$ anakan paling rendah berasal dari populasi Carita, sebaliknya nilainya tinggi pada populasi SBK. Carita merupakan hutan tanaman sedangkan SBK merupakan hutan alam, dengan jumlah pohon induk yang berimbang, masing-masing sebanyak 18 di Carita dan 12 di SBK (Tabel 1). Tabel 3 memperlihatkan bahwa potensi genetik di populasi SBK lebih baik dibandingkan Carita. Tingginya jumlah alel yang terdeteksi juga menunjukkan potensi genetik dimiliki oleh populasi SBK. Namun demikian, nilai koefisien inbreeding anakan dari populasi SBK secara signifikan menunjukkan kelebihan homozigositas atau menyimpang dari hukum keseimbangan Hardy-Weinberg. Hasil ini menunjukkan keberhasilan proses reproduksi di populasi SBK tidak terjadi secara acak seperti pada populasi lainnya. Banyak faktor yang mempengaruhi keberhasilan proses reproduksi di hutan alam, diantaranya fenologi pembungaan antar individu, sinkronisasi pembungaan antar individu seringkali sulit terjadi karena tingkat umur masing-masing individu berbeda (Law dkk., 2000; Torimaru dan Tomaru, 2006; Brearley dkk., 2007; Setsuko dkk., 2008). Selain itu, keberhasilan proses reproduksi dipengaruhi juga oleh distribusi pohon. Pada populasi yang terfragmentasi, aliran gene melalui serbuk sari terhambat (Lian dkk., 2001; Fuchs dkk., 2003; Ozawa dkk., 2012). Sebagai contoh, di hutan alam yang terfragmentasi pada Pinus densiflora, anakan-anakan yang dihasilkan merupakan hasil perkawinan dengan satu tetua jantan (Lian dkk., 2001; Ozawa dkk., 2012). 
Analisis PCA dan dendogram menggunakan UPGMA menunjukkan pengelompokkan yang sama antara 6 populasi S. leprosula. Pengelompokkan berdasarkan jarak genetik ini berhubungan erat dengan jarak/ posisi geografis. Hasil analisis PCA dan dendogram sama-sama menunjukkan bahwa empat populasi yaitu GBA, SBK, ITCI dan GL saling berdekatan sedangkan populasi Carita dan GBB terpisah. Apabila analisis PCA dan dendogram dihubungkan dengan jarak geografisnya (Gambar 1), keempat populasi tersebut secara geografis juga berdekatan. Hasil AMOVA juga menunjukkan masing-masing populasi berbeda secara genetik. Populasi Carita yang merupakan hutan tanaman secara geografis terpisah dengan populasi dari Kalimantan. Hal ini kemungkinan karena sumber materi genetik tanaman S.leprosula yang di Carita tidak berasal dari 5 populasi Kalimantan yang digunakan dalam penelitian ini atau berasal dari populasi yang berbeda.

Rata-rata jarak genetik dari 6 populasi S. leprosula adalah 0,327. Untuk 5 populasi alam, populasi GBA dan GBB mempunyai jarak genetik yang terjauh yaitu 0,460 , walaupun secara geografis cenderung dekat dibandingkan GBA dengan populasi alam yang lain. Tetapi populasi GBA, SBK, ITCI dan GL berada pada sisi selatan dari Pulau Kalimantan, sedangkan populasi GBB lebih ke sisi utara (Gambar 1). Kemungkinan populasi di sisi selatan pada awalnya berasal dari populasi yang sama. Walaupun demikian, jarak genetik antar populasi termasuk sedang sampai tinggi karena jarak genetik yang terendah adalah 0,178 yang berarti terdapat perbedaan genetik sebesar $17,8 \%$.

Hasil dari penelitian ini, seperti yang disampaikan pada pendahuluan, diharapkan dapat digunakan untuk materi genetik uji klon S. leprosula. Beberapa hasil penting dari penelitian ini adalah keragaman genetik dari masing-masing populasi cukup tinggi, terjadinya pengelompokkan dari 6 populasi menjadi 3 kelompok besar, dan jarak genetik yang relatif cukup besar antara 6 populasi S. leprosula. Informasi lain yang juga bermanfaat adalah kekayaan alel dari masing-masing populasi dan signifikansi terjadinya inbreeding pada populasi SBK. Dengan hasil dan informasi tersebut di atas, beberapa pertimbangan yang dapat diberikan untuk kegiatan uji klon S. leprosula adalah sebagai berikut: 
1. Jumlah populasi yang digunakan minimal adalah 3 berdasarkan dendrogram atau PCA. Tetapi bila memungkinkan, sampel juga diambil dari 4 populasi yang tergabung menjadi 1 kelompok dikarenakan jarak genetik antar populasi cukup tinggi.

2. Jumlah individu/anakan dapat merata untuk masing-masing populasi. Untuk populasi dengan jumlah alel dan kekayaan alel yang lebih tinggi, jumlah individunya dapat lebih banyak. Untuk populasi SBK dengan kekayaan lalel yang tertinggi, heterosigositas dari masing-masing individu perlu diperhatikan mengingat signifikannya inbreeding pada populasi tersebut.

Hasil dari penelitian ini, tidak hanya bermanfaat untuk mendukung kegiatan pemuliaan dari $S$. leprosula, tetapi juga dapat dimanfaatkan untuk menyusun strategi konservasi, baik itu eks-situ maupun in-situ.

\section{KESIMPULAN}

Studi keragaman genetik populasi $S$. leprosula menggunakan materi genetik dari anakan tidak hanya memberikan informasi mengenai keragaman genetik pohon induk penyusun populasi, tetapi juga dapat menggambarkan sistem perkawinan yang terjadi di dalam populasi tersebut. Informasi mengenai jarak genetik antar populasi maupun pengelompokkan populasi berdasarkan jarak genetik dapat juga diberikan. Rata-rata nilai keragaman genetik yang cukup tinggi dari masing-masing populasi dan jarak genetik yang cukup besar antara populasi memberikan kesempatan yang cukup besar untuk melakukan pemuliaan terhadap jenis S. leprosula.

Pemilihan jumlah anakan per populasi maupun populasi yang dipilih dapat dilakukan menggunakan hasil penelitian ini. Pertimbangan untuk penentuan tersebut harus berdasarkan pada jumlah alel yang terdapat dalam masing-masing populasi dan kekayaan alel yang dimilikinya, keragaman genetik dalam populasi dan pengelompokkan populasi. Populasi yang mempunyai keragaman yang tinggi seperti SBK dapat menjadi prioritas untuk jumlah individu anakan yang lebih banyak daripada populasi lainnya, tetapi heterosigositas anakan perlu diperhatikan karena tingkat inbreeding yang signifikan pada populasi tersebut. 


\section{DAFTAR PUSTAKA}

Adriyanti, D. W., Subiakto, A. dan Kumala. 2005. Shorea leprosula Miq. . Informasi Jenis No. 001/ITTO-PD41/05 Proyek ITTO PD 41/00 Rev. 3 (F,M). Fakultas Kehutanan Universitas Gadjah Mada. Yogyakarta.

Brearley, F. Q., Proctor, J., Suriantata, Nagy, L., Dalryple, G. and Voysey, B. C. 2007. Reproductive Phenology Over a 10 -yearPeriode in a Lowland Evergreen Rain Forest of Central Borneo. Journal of Ecology, 95: 828-839.

Butcher, P. A., Glaubitz, J. C. and Moran, G. F. 1999. Applications For Microsatellite Markers In The Domestication And Conservation of Forest Trees. Forest Genetics Resources Information, 27: 34-42.

Cao, C-P., 2006. Genetic variation of the genus Shorea (Dipterocarpaceae) in Indonesia. Faculty of Forest Sciences and Forest Ecology, Georg-August University of Göttingen. Göttingen, Göttingen. Doctoral: 131.

Cao, C-P., Gailing, O., Siregar, I. Z., Siregar, U. J. and Finkeldey, R. 2009. Genetic variation in nine Shorea species (Dipterocarpaceae) in Indonesia revealed by AFLPs. Tree Genetics \& Genomes 5(407-420): 407-420.

Chase, M., Kesseli, R. and Bawa, K. 1996. Microsatellite Markers For Population And Conservation Genetics Of Tropical Trees. American Journal of Botany, 83: 173-181.

Fuchs, E. J., Lobo, J. A. and Quesada, M. 2003. Effects of Forest Fragmentation and Flowering Phenology on the Reproductive Success and Mating Patterns of the Tropical Dry Forest Tree Pachira quinata. Conservation Biology, 17(1): 149-157.

Fukue, Y., Kado, T., Lee, S. S., Ng, K. K. S., Muhammad, N. and Tsumura, Y. 2007. Effects of flowering tree density on the mating system and gene flow in Shorea leprosula (Dipterocarpaceae) in Peninsular Malaysia. Journal of Plant Research, 120(3): 413-420.

Glaubitz, J. C. and Moran, G. F. 2000. Genetic Tools: The Use of Biochemical and
Molecular Markers. Forest Conservation Genetics. A. Young, D. Boshier and T. Boyle. Australia, CSIRO Publishing: 39-59.

Isoda, K., Yasman, I., Rimbawanto, A. and Prihatini, I. 2001. Estimation of Genetic Variation of Shorea leprosula in The Hedge-orchard of the Inhutani I Dipterocarp Center East Kalimantan using DNA Markers. International Seminar Proceeding : In-situ and exsitu conservation tropical trees Faculty of Forestry, Gadjah Mada University, Yogyakarta.

Law., B., Mackowski, C., Schoer, L. and Tweedie, T. 2000. Flowering phenology of myrtaceous trees and their relation to climatic, environmental and disturbance variables in northern New South Wales. Australian Ecology, 25: 160-178.

Lee, S. L. 2000. Mating System Parameters in A Tropical Tree Species, Shorea leprosula Miq. (Dipterocarpaceae), from Malaysian Lowland Dipterocarp Forest. BIOTROPICA, 32(4a): 693-702.

Lee, S. L., Ang, K. C. and Norwati, M. 2000. Genetic Diversity of Dryobalanops aromatica Gaertn.F. (Dipterocarpaceae) In Peninsular Malaysia and Its Pertinence to Genetic Conservation and Tree Improvement. Forest Genetics, 7(3): 211-219.

Lee, S. L. 2000. Genetic Diversity of a Tropical Tree Species, Shorea leprosula Miq. (Dipterocarpaceae), in Malaysia: Implications for Conservation of Genetic Resources and Tree Improvement. BIOTROPICA, 32(2): 213-224.

Lemmens, R. H. M. J. and Soerianagara, I. 1994. Timber Trees: Major Commercial Timbers. Plant Resources of South-East Asia. Prosea Foundation. Bogor 5(1).

Lestyaningsih, I., Nai'em, M. dan Winarni, W. W. 2005. Variasi Isozim Meranti merah (Shorea leprosula Miq.) dari Sumatera pada Tegakan Konservasi Ex-Situ. Dalam: Hardiyanto, E.B (Ed). Peran Konservasi Sumber Daya Genetik, Pemuliaan dan Silvikultur Dalam Mendukung Rehabilitasi Hutan. Prosiding Seminar Nasional Peningkatan Produktifitas Hutan. Fakultas Kehutanan UGM \& International Tropical Timber 
Organization. 359-371.

Lian, C., Miwa, M. and Hogetsu, T. 2001. Outcrossing and paternity analysis of Pinus densiflora (Japanese red pine) by microsatellite polymorphism. Heredity, 87: 88-98.

Murawski, D. A. and Bawa, K. S. 1994. Genetic Structure and Mating System of Stemonophorus oblongifolius (Dipterocarpaceae) in Sri Lanka. American Journal of Botany, 81(2): 155160.

Nai'em, M., Raharjo, P. dan Wardana, E. K. 2005. Evaluasi Awal Uji Keturunan Shorea leprosula Miq. di PT. ITCI KU, Kalimantan Timur. Dalam: Hardiyanto, E.B (Ed). Peran Konservasi Sumber Daya Genetik, Pemuliaan dan Silvikultur Dalam Mendukung Rehabilitasi Hutan. Prosiding Seminar Nasional Peningkatan Produktifitas Hutan. Fakultas Kehutanan UGM \& International Tropical Timber Organization 193-201.

Ozawa, H., Watanabe, A., Uchiyama, K., Saito, Y. and Ide, Y. 2012. Genetic diversity of Pinus densiflora pollen flowing over fragmented populations during a mating season. Journal Forestry Research, 17: 488-498.

Peakall, R. and Smouse, P. E. 2006. GENALEX 6: genetic analysis in Excel, Population genetic software for teaching and research. Molecular Ecology Notes, 6: 288-295.

Prihatini, I., Rimbawanto, A. and Isoda, K. 2001. Population genetic study of Shorea leprosula using RAPDs (Random Amplied Polymorphic DNAs). In : Thielges, B.A., Sastrapraja, S.D., and Rimbawanto, A. (Eds):In-situ and ex-situ conservation tropical trees. Proceeding International Seminar. Faculty of Forestry, Gadjah Mada University, Yogyakarta. ( 505-510).

Rayan dan Cahyono, D. D. N. 2012. Eksplorasi Pengumpulan Materi Genetik Shorea leprosula Miq. untuk Populasi Dasar dan Populasi Pemuliaan. Info Teknis Dipterokarpa, 5(1): 35-45.

Rimbawanto, A. and Isoda, K. 2001. Genetic structure of Shorea leprosula in a single population revealed by microsatellite markers. In : Thielges, B.A., Sastrapraja,
S.D., and Rimbawanto, A. (Eds): Insitu and ex-situ conservation tropical trees. Proceeding International Seminar. Faculty of Forestry, Gadjah Mada University, Yogyakarta,: 333-340.

Rimbawanto, A. dan Suharyanto. 2005. Keragaman Genetik Populasi Shorea leprosula Miq. dan Implikasinya Untuk Program Konservasi Genetik. Dalam: Hardiyanto, E.B (Ed). Peran Konservasi Sumber Daya Genetik, Pemuliaan dan Silvikultur Dalam Mendukung Rehabilitasi Hutan. Prosiding Seminar Nasional Peningkatan Produktifitas Hutan. Fakultas Kehutanan UGM \& International Tropical Timber Organization. 373-382.

Rudjiman. 1997. Identifikasi 15 Jenis Anggota Genus Shorea Roxb. di Kalimantan Tengah. Yogyakarta, Fakultas Kehutanan UGM. .

Rudjiman and Adriyanti, D. T. 2002. Identification Manual of Shorea spp. ITTO PD 16/96 Rev. 4 (F). Yogyakarta, Faculty of Forestry Gadjah Mada University.

Sastrapradja, S., Kartawinata, K., Roesmantyo, U., Soetisna, Wiriadinata, H. dan Riswan, S. 1997. Jenis-jenis Kayu di Indonesia. Proyek Sumberdaya Ekonomi. LBNLIPI. Bogor.

Sayektiningsih, T. 2010. Mengenal Ciri Morfologi Beberapa Jenis Buah Famili Dipterocarpaceae. Mitra Hutan Tanaman, 5(1): 15-19.

Suzuki, S., Tamaki, I., Ishida, K. and Tomaru, N. 2008. Relationships Between Flowering Phenology and Female Reproductive Success in The Japanese Tree Species Magnolia stellata. Botany, 86: 248-258.

Shiraishi, S. and Watanabe, A. 1995. Identification of chloroplast genome between Pinus densiflora Sieb et Zucc and $P$. thumbergii Parl based on the polymorphism in $r b c \mathrm{~L}$ gene. Journal of Japanese Forestry Society, 77: 429-436.

Siregar, U. J. 2001. Genetical studies for conservation of tropical timber species in Indonesia. In:Thielges, B.A.,Sastrapraja, S.D.,Rimbawanto, A. (Eds):In-situ and ex-situ conservation tropical trees. Proceeding International Seminar., Faculty of Forestry, Gadjah Mada University, Yogyakarta. 
Soekotjo. 2001. The status of ex-situ conservation of commercial tree species in Indonesia. In : Thielges, B.A., Sastrapraja, S.D., and Rimbawanto, A. (Eds):In-situ and ex-situ conservation tropical trees. Proceeding International Seminar. Faculty of Forestry, Gadjah Mada University, Yogyakarta: 147-160.

Suseno, O. H. 2001. Current status of tree improvement in Indonesia. In Thielges, B.A., Sastrapraja, S.D., and Rimbawanto, A. (Eds):In-situ and exsitu conservation tropical trees. Faculty of Forestry, Gadjah Mada University, Yogyakarta: 231-261.

Tani, N., Tsumura, Y., Kado, T., Taguchi, Y., Lee, S. L., Muhammad, N., Ng, K. K. S., Numata, S., Nishimura, S., Konuma, A. and Okuda, T. 2009. Paternity analysisbased inference of pollen dispersal patterns, male fecundity variation, and influence of flowering tree density and general flowering magnitude in two dipterocarp species. Annals of Botany, 104: 1421-1434.
Tauntz, D. 1989. Hypervariability of Simple Sequences As A General Source for Polymorphic DNA Markers. Nucleic Acids Research, 25: 6463-6471.

Torimaru, T. and Tomaru, N. 2006. Relationships between flowering phenology, plant size, and female reproductive output in a dioecious shrub, Ilex leucoclada (Aquifoliaceae). Canadian Journal of Botany, 84: 1860-1869.

Ujino, T., Kawahara, T., Tsumura, Y., Nagamitsu, T., Yoshimaru, H. and Wickneswari, R. 1998. Development and polymorphism of simple sequnce repeat DNA markers for Shorea curtisii and other Dipterocarpaceae species. Heredity, 81: 422-428. 